A Markusovszky Egyetemi Oktatókórház, Ortopédiai Sebészeti Osztály', Traumatológiai és Kézsebészeti Osztály², Szombathely, a Pécsi Tudományegyetem, Általános Orvostudományi Kar, Traumatológiai és Kézsebészeti Klinika ${ }^{3}$, és az Eötvös Lóránd Tudományegyetem, Savaria Egyetemi Központ, Természettudományi centrum, Savaria Biológiai Tanszék ${ }^{4}$ közleménye

\title{
Elülső feltárásból végzett minimál invazív csípőprotézis beültetés korai funkcionális eredményeinek vizsgálata
}

\author{
DR. GOMBOS ÁRMIN ${ }^{1,2}$, DR. MOLNÁR PÉTER ${ }^{4}$, DR. BÜCS GÁBOR ${ }^{3}$, \\ DR. TORKOS MIKLÓS BULCSÚ', DR. DE JONGE TAMÁS ${ }^{1}$
}

Érkezett: 2018. szeptember 26.

DOI: 10.21755/MTO.2019.062.0102.004

\section{ÖSSZEFOGLALÁS}

Az utóbbi időben egyre népszerúbbé vált a minimál invazív, direkt elülső feltárás alkalmazása a totál csípőizületi endoprotézis beültetések során. Jelen közleményben a szerzők célja az ezen technikával elérhető korai funkcionális javulás szemléltetése. Prospektív tanulmányukban 63 elülső feltárásból operált páciens preoperatív, posztoperatív 4-5. napos, hathetes, valamint három hónapos Oxford Hip Score és Harris Hip Score adatait elemezték. Már a posztoperatív 4-5. napra szignifikáns javulást detektáltak, amelyhez képest további szignifikáns javulást észleltek a posztoperatív hatodik hétre. A posztoperatív harmadik hónapra nem következett be további szignifikáns javulás a páciensek állapotában. A szerzők megállapítják, a direkt anterior feltárásban végzett csípőízületi totál endoprotézis beültetés által nyerhető funkció végleges állapota már a posztoperatív hatodik hétre kialakul. Ezáltal a minimál invazív, direkt anterior feltárás lehetőséget teremt a totál csípőízületi endoprotézis beültetésen áteső betegek korai és gyors felépülésére és rehabilitációjára.

\section{Kulcsszavak: $\quad$ Arthroplastica, csípö; Csípöprotézis beültetés; Minimál invazív ellátás; Funkcionális eredmények;}

Á. Gombos, P. Molnár, G. Bücs, M. B. Torkos, T. de Jonge: Measurement of early functional outcomes of total hip replacement through the minimally invasive direct anterior approach

Total hip replacement through the minimally invasive direct anterior approach has become more and more popular. The aim of this paper is to demonstrate the early outcomes achieved with this technique. In this prospective study 63 patients were evaluated by the Oxford Hip Score and the Harris Hip Score preoperatively and postoperatively at 4-5 days, six weeks, and three months. In case of the postoperative 4-5 days there has already been a significant improvement, continued to be detectable by the postoperative sixth week. There was no further significant improvement by the postoperative third month. The authors conclude that patients going through total hip replacement with direct anterior approach reach the final state of their better function arising from the operation by the postoperative sixth week. Therefore, the minimally invasive direct anterior approach for total hip replacement provides early and fast recovery and rehabilitation.

Keywords: $\quad$ Arthroplasty, replacement, hip-Methods;

Surgical procedures, minimally invasive - Methods;

Treatment Outcome; 


\section{BEVEZETÉS}

A csípőízületi endoprotetika az egyik legsikeresebb és leggyakrabban végzett elektív ortopéd sebészeti beavatkozás. A fájdalom hosszú távú csökkenését, megbízható és kiegyensúlyozott klinikai funkciót, valamint szignifikánsan fokozott életminőséget jelent korábban fájdalmas, csökkent mozgástartományú, coxarthrosistól szenvedő emberek millióinak világszerte. Fontosságát fémjelzi, hogy jelenleg több mint 1 millió arthroplasticát végeznek évente a világon, és ez a szám előreláthatólag duplázódni fog a következő két évtizedben (8). A mútét indikációja az esetek $90 \%$-ában a szimptómás coxarthrosis, amely növekvő incidenciát mutat az öregedő populáció és az epidémiás obesitas miatt. A fiatalabb páciensek aránya egyre növekszik (9). Ezek a fiatalabb páciensek fokozott elvárásokkal kerülnek mútétre, remélve, hogy viszszatérhetnek a korábbi, jellemzően fizikálisan megterhelő aktivitással járó életmódjukhoz. Ezen tényeken alapulva érthető, hogy a totál csípő endoprotetikában egyre hatékonyabb eszközök, implantátumok és mútéti eljárások kifejlesztése és alkalmazása szükséges. Ilyen eljárás, az utóbbi időben egyre népszerűbbé váló, minimál invazív, direkt anterior feltárás, amely technika számos előnnyel rendelkezik: kisebb izomsérülés $(4,11,18)$, kisebb posztoperatív fájdalom $(1,2,5,6,13,19,20)$ és fájdalomcsillapító igény $(15,20)$, gyorsabb funkcionális javulás $(2,12,14,18,19)$, koraibb járási képesség $(12,13,17)$, a járási segédeszközök koraibb elhagyása $(13,17,20)$, rövidebb hospitalizáció $(1,2,6,15,20)$, valamint magasabb Harris Hip Score értékek a korai posztoperatív időszakban (2, 3, 13, 17-19). Ezen előnyök elsősorban a korai posztoperatív időszakra vonatkoznak. A hosszabb távú eredményeket tekintve már nincs szignifikáns különbség a különböző mútéti feltárások között. A posztoperatív hatodik hónapra a különböző feltárásokkal végzett operációk eredményei közötti különbség a tanulmányok többsége szerint eltűnik $(2,19)$, azonban Restrepo és munkatársai szerint a direkt lateralis feltárással nyert eredmények csak a posztoperatív második évre érik el a direkt anterior feltárásban operált betegek eredményeit (13). Ezek alapján a korai funkcionális eredmények értékelése hordoz magában jelentős információt a totál csípőízületi endoprotézis beültetéséhez használatos feltárások vizsgálata során.

A legjobb hatékonysággal rendelkező feltárás a totál csípő endoprotézis beültetéshez - a rendelkezésre álló irodalmi adatok alapján - továbbra is vita tárgya. A direkt anterior feltárás elvitathatatlan előnye azonban a korai funkcionális javulás kiemelkedő mértéke. Tanulmányunk célja ezen hamar kialakuló jó funkcionális eredmények felmérése saját beteganyagunkon.

\section{ANYAG ÉS MÓDSZER}

Vizsgálatunk során az adatgyűjtés prospektív módon, 2018. februártól 2018. decemberig zajlott a szombathelyi Markusovszky Egyetemi Oktatókórház Ortopédiai Sebészeti Osztályán. Az operációkat két, a minimál invazív, direkt anterior feltárás végzésében megfelelő tapasztalattal rendelkező sebész végezte. A mütéteket körültekintő preoperatív tervezéssel, a páciens hanyatt fekvő helyzetében, standard mútőasztalon, trakciós eszköz alkalmazása nélkül, hagyományos múszerkészlet használatával, a végtaghossz manuális ellenőrzésével, intraoperatív röntgen átvilágítás nélkül végezték. $A$ femoralis protéziskomponens beültetéséhez a csípőízület hyperextenziója a mútőasztal megtöretésének segítségével vált elérhetővé (1-2. ábrák). A betegek mobilizálása gyógytornász segítségével a mútétet követő napon vette kezdetét. Multimodális fájdalomcsillapítás keretében a páciensek a mútét napján és a posztoperatív első napon parenterálisan, a posztoperatív második naptól per os részesültek analgetikus terápiában. A mútéttel kapcsolatos vérzés csökkentése érdekében valamennyi páciens közvetlenül a beavatkozás előtt $1 \mathrm{~g}$ tranexam savat kapott intravénásan, melyet a mútét befejezését követően 2 órával fél dózisban ismételtek. Kontrollált hypotensio alkalmazására nem került sor egyetlen esetben sem.

A betegek adatai előre meghatározott szempontok alapján kerültek rögzítésre: életkor, nem, BMI, coxarthrosis oldalisága, mútét időtartama, mútét utáni vérzés mennyisége (a posztoperatív első 48 órában a drénen ürült vér mennyisége). Felvételre kerültek még az Oxford Hip Score (OHS) és a Harris 
Hip Score (HHS) értékei preoperatíve, valamint a kórházból való távozás napján - amely a fent nevezett osztály protokollja alapján a posztoperatív 4-5. napot jelenti - továbbá a posztoperatív hatodik hét és harmadik hónap kontrollja során.

Elemzésre került a különböző időpontokban felvett OHS és HHS pontszámok változásának mértéke, különös tekintettel a hathetes és három hónapos adatok összehasonlítására. Utóbbi időpontok között külön értékelésre került a HHS által felmért fájdalom és funkció mértéke, valamint a korlátlan járástávval bíró, lépcsőt normálisan használni tudó (korláttal vagy nélküle), és cipőt, illetve zoknit könynyedén fel- és levevő páciensek aránya. Ezzel célunk a hathetes és három hónapos adatok árnyaltabb összehasonlítása volt.

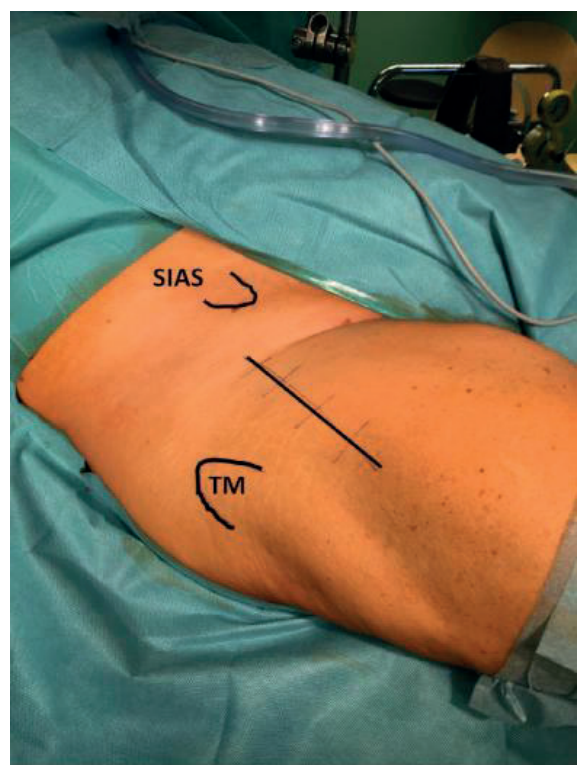

\section{1. a ábra}

73 éves férfibeteg $(170 \mathrm{~cm}, 113$ kg, BMI: 39,1 tipikusan előnytelen testalkat) jobb oldali mútét elött. A börmetszés helye a spina iliaca anterior superiortól (SIAS) distalisan és lateralisan indul 2-3 cm-rel, lehetöség szerint a m. tensor fasciae latae izomhasának a középtengelyében distal és enyhén lateral irányban (a fibulafej felé), kb. $10 \mathrm{~cm}$ hosszan (TM: trochanter maior)

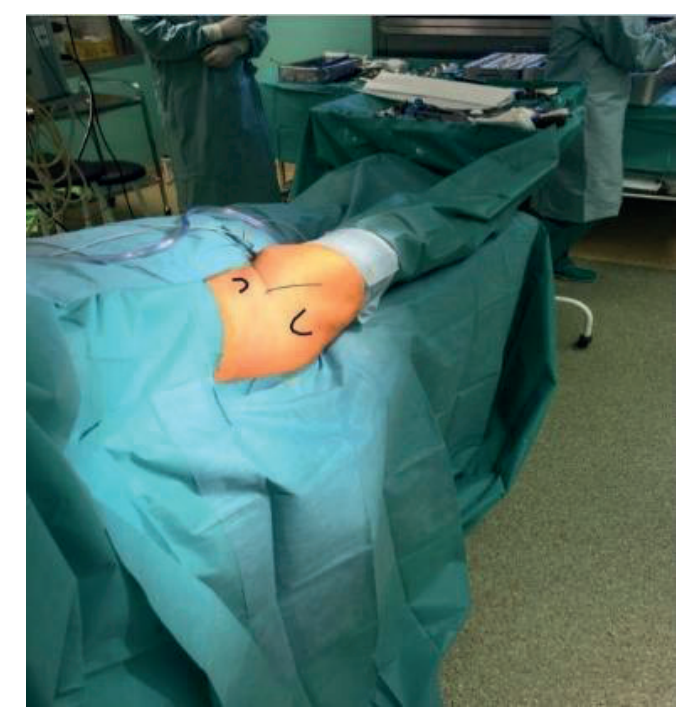

\section{1. $b$ ábra}

A páciens hanyattfekvő helyzetében, a medence kiemelése nélkül történik a beavatkozás, hagyományos mútöasztalon, trakció alkalmazása mellözésével. A börfertőtlenítést és izolálást hagyományos módon végezzük, csak az operált végtagot hagyjuk szabadon 


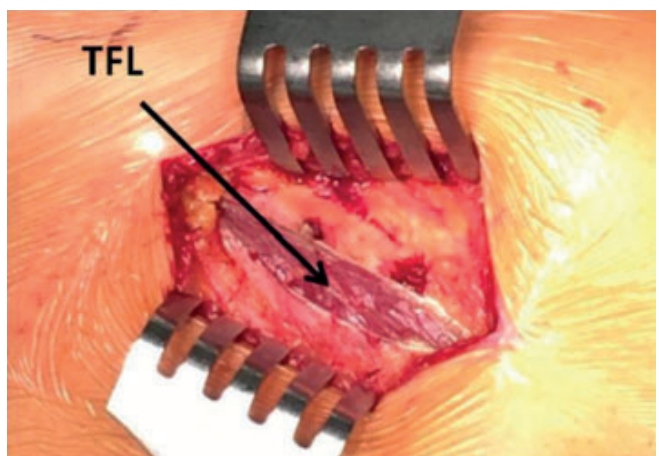

1. c ábra

A fascia behasítása a börmetszés tengelyében történik, szabaddá válnak a tensor izom ferdén distal futó rostjai (TFL: $m$. tensor fasciae latae)

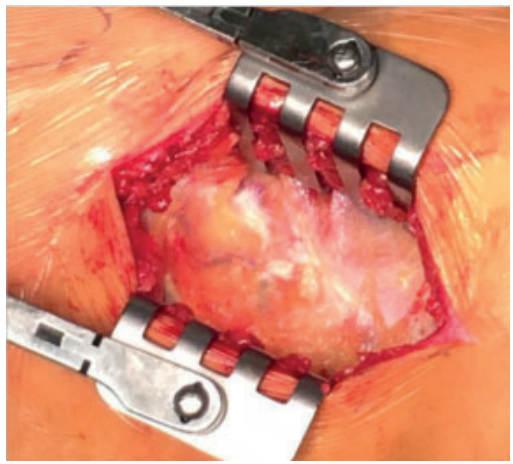

\section{1. e ábra}

A rectus femoris izmot medial felé eltartva a mélyben a fascia innominata látható. A rectus femoris izom lateralis széle mentén történő hosszanti behasitása során ügyelni kell az a. circumflexa ant. ágrendszerére, melyet gondosan koagulálni, vagy lekötni szükséges

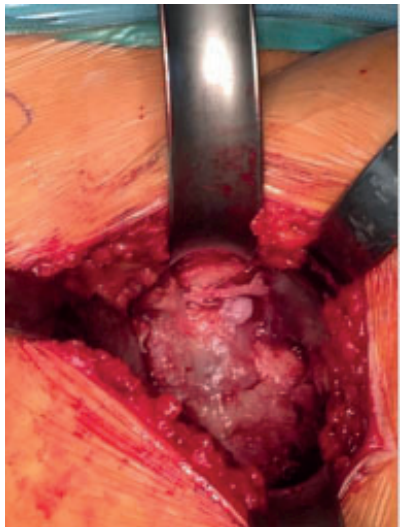

1. g ábra

Az arthroticus proximalis femurvég direkt anterior feltárásból

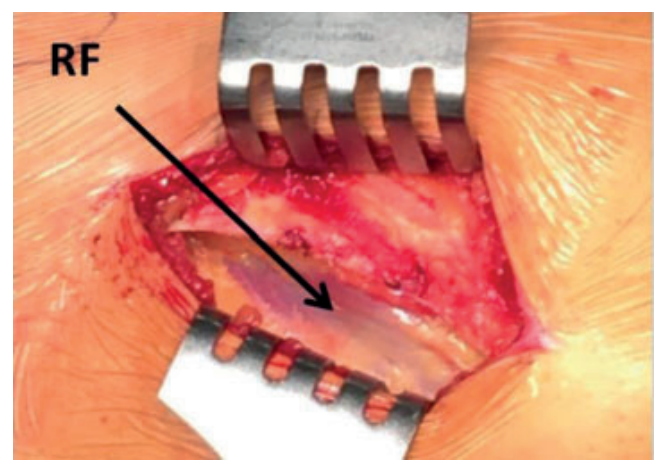

1. d ábra

A tensor izomhasat lateral felé elkampózva medialisan az izompólyán áttünő rectus femoris izom látható (RF)

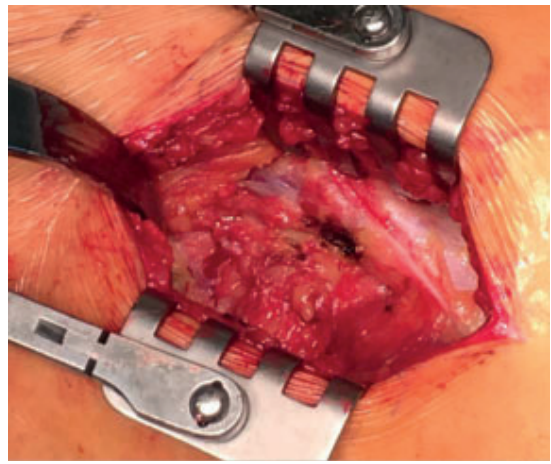

\section{1. $f a ́ b r a$}

A fascia innominata hosszanti behasitása után a precapsularis zsírszövet látható. Az ízületi tok tisztázása után a szokásos capsulotomia, majd a nyak osteotomia következik

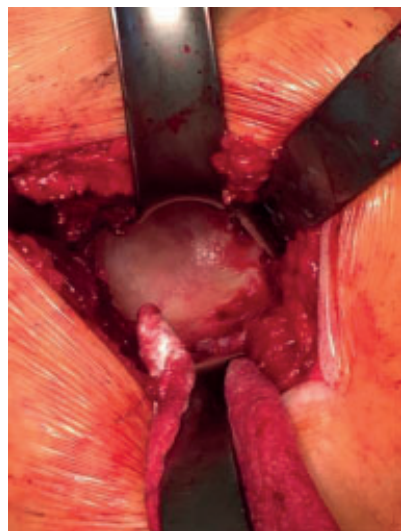

\section{1. $h$ ábra}

A combfej eltávolítását követöen tökéletesen vizualizálható az acetabulum 


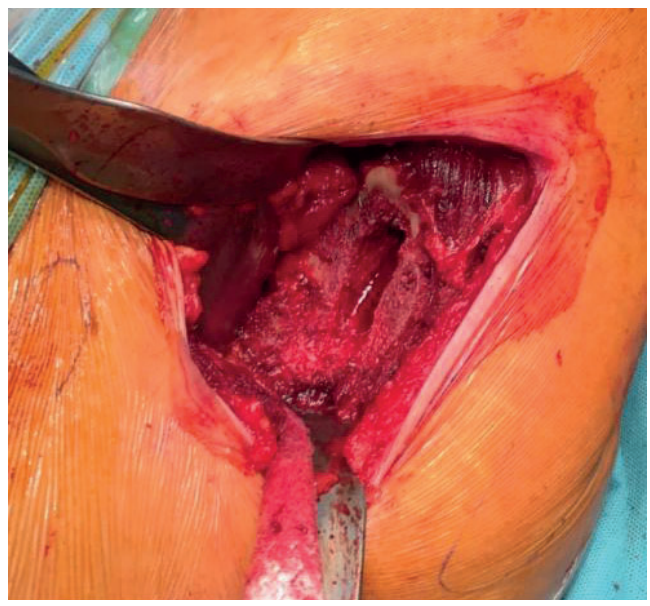

\section{1. i ábra}

A lágyrészfelszabaditást követően az elönytelen alkatú betegnél is jól hozzáférhetövé válik a femur velöürének bemenete
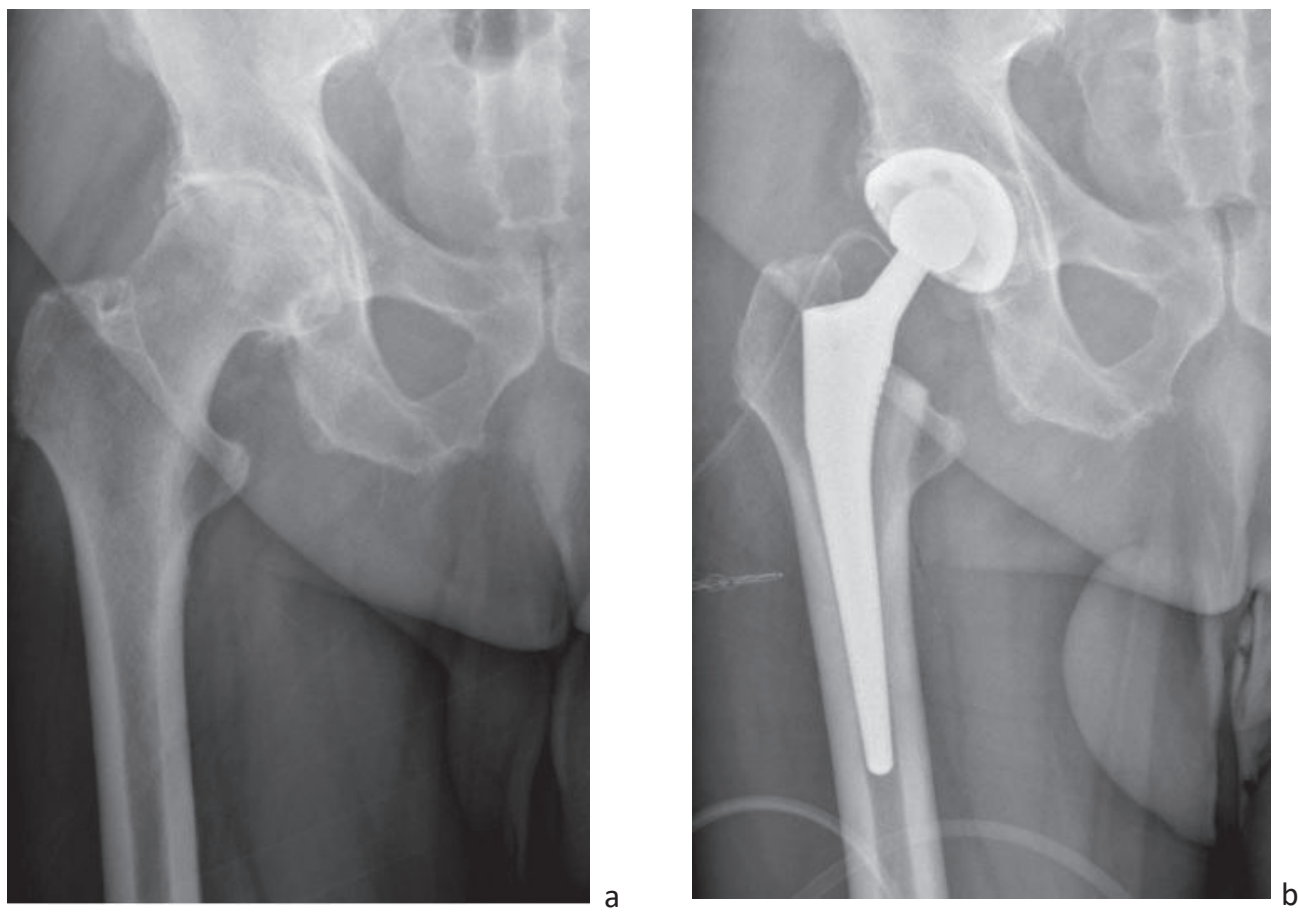

\section{2. ábra}

a) az intraoperativ képeken bemutatott páciens preoperativ és b) posztopeativ röntgenfelvétele 


\section{Statisztikai módszerek}

$\mathrm{Az}$ adatok kiértékelését SPSS 22 programmal végeztük (10). A különböző időpontokban kapott OHS és HHS pontszámok átlagolásra kerültek az idő függvényében, így négy csoportot kaptunk: preoperativ, posztoperatív 4-5. nap, posztoperatív hatodik hét és posztoperatív harmadik hónap. A saját adatainkon végzett normalitásvizsgálat alapján nem lehetett kizárni, hogy az OHS és HHS pontszámok nem normál eloszlásúak, ezért mind a parametrikus, mind a nem parametrikus teszteket elvégeztük a hipotézis teszteléshez (16).

Az OHS pontszám esetén elvégeztük mind az önkontrollos, mind a csoportátlagok kiértékelését. Parametrikus tesztként az önkontrollos esetben párosított Student's t-tesztet használtuk, a csoportátlagok összehasonlítására ANOVA tesztet alkalmaztunk Tukey-féle Post Hoc teszttel. Nem parametrikus tesztként a Wilcoxon, Kruskal-Wallis és Mann-Whitney teszteket használtuk. Az HHS pontszámok esetén parametrikus tesztként ANOVA tesztet futtattunk Tukey-féle Post Hoc teszttel, nem parametrikus tesztként pedig Kruskal-Wallis tesztet és Mann-Whitney Post Hoc páronkénti összehasonlítást használtunk. A HHS alapján számított fájdalom és funkció részpontszámokat Mann-Whitney teszttel hasonlítottuk össze. A kategorikus adatokat (sétatávolság, lépcsőhasználat, valamint cipő- és zokni fel- és levétel) McNemar teszttel értékeltük (2).

\section{EREDMÉNYEK}

A vizsgálatba 63 páciens került bevonásra, átlagos életkoruk a mútét idején 69,9 év volt. A betegek 43\%-a (27 fő) volt férfi és 57\%-a (36 fő) volt nő. 38 esetben jobb oldali, 25 esetben bal oldali beavatkozás történt (I. táblázat).

A mútétek átlagos időtartama $73 \pm 18$ perc volt, a posztoperatív első 48 órában való vérzés (a dréneken ürült vér mennyisége) pedig $622 \pm 269 \mathrm{ml}$-nek adódott.

A funkciójavulás időbeli lefutásának vizsgálatát illetően az OHS adatok önkontrollos elemzése során a preoperatív értéket $100 \%$ nak $(99,98 \%)$ véve, a hatodik posztoperatív hétre 163,21\%-os javulás következett be, így a hathetes érték 263,19\%-nak adódott (párosított Student's t-teszt: $p=0,00$; Wilcoxon teszt: $p=0,01)$. A hatodik heti értékekhez képest a posztoperatív harmadik hónap 255,67\%-os értéke 7,52\%-os csökkenést jelentett, amely azonban nem szignifikáns különbség a két időpont pontszámai között (párosított Student's t-teszt: $p=0,687$; Wilcoxon teszt: $p=0,152$ ), (3. ábra).

$\mathrm{Az}$ OHS adatok csoportátlagos értékelése során a preoperatív pontszám 15,1 $\pm 8,7$ lett, ami gyenge eredménynek minősül. Ez az érték a 4-5. posztoperatív napra még mindig a gyenge kategóriába esett $(23,5 \pm 10,9)$, azonban szignifikánsan javult (Tukey: $p=0,04$; Mann-Whitney: $\mathrm{p}=0,04)$. A posztoperatív hatodik heti OHS már a jó kategóriába esett $(36 \pm 8,1)$, ez további szignifikáns javulást jelentett a 4-5. napos értékhez képest (Tukey: $p=0,00$; Mann-Whitney: $p=0,00$ ). A három hónapos értékek $(38 \pm 8,9)$ nem mutattak további szignifikáns javulást a hathetes értékekhez képest (Tukey: $p=9,33$; Mann-Whitney: $\mathrm{p}=0,302$ ) (4. ábra).

A HHS pontszámokat tekintve a preoperatív érték $(42,2 \pm 15,1)$ a gyenge tartományba esett. A posztoperatív $4-5$. napos értékek ugyan javulást mutattak $(53,4 \pm 16,2)$, azonban ez az eltérés nem volt szignifikáns (Tukey: $p=1,86$; MannWhitney: $p=0,61)$. A posztoperatív hatodik hét értékei $(79,7 \pm 14,0)$ már szignifikáns javulást mutattak a preoperatív adatokhoz képest, ekkor már az elfogadható tartomány felső felébe estek (Tukey: $p=0,00$; Mann-Whitney: $p=0,00$ ). A három hónapos HHS pontszám értéke már a jó tartományba esett $(81,0 \pm 16,4)$, azonban ez nem jelentett szignifikáns változást a hathetes értékekhez képest (Tukey: $p=0,986$; Mann-Whitney: $\mathrm{p}=0,344$ ) (5. ábra, II. táblázat).

A HHS részpontszámok értékelése során sem találtunk szignifikáns különbséget a hathetes és a három hónapos adatok között. $A$ hatodik héten felvett fájdalom részpontszám $(36,6 \pm 8,7)$ kis mértékben romlott $(35,6 \pm 6,9)$, a funkció részpontszám $(35,1 \pm 10,0)$ pedig kis mértékben javult $(37,4 \pm 7,4)$ a harmadik hónapra, azonban egyik változás sem volt szignifikáns (MannWhitney rendre: $\mathrm{p}=0,445 ; \mathrm{p}=0,201$ ) (6. ábra).

Hasonlóképpen a kategorikus változók (korlátlan járástávval rendelkező, lépcsőt normálisan használni tudó, cipőt és zoknit könynyedén fel- és levevő páciensek) arányában sem volt szignifikáns eltérés a hathetes és a három hónapos posztoperatív időpontok között (7. ábra, III. táblázat). 


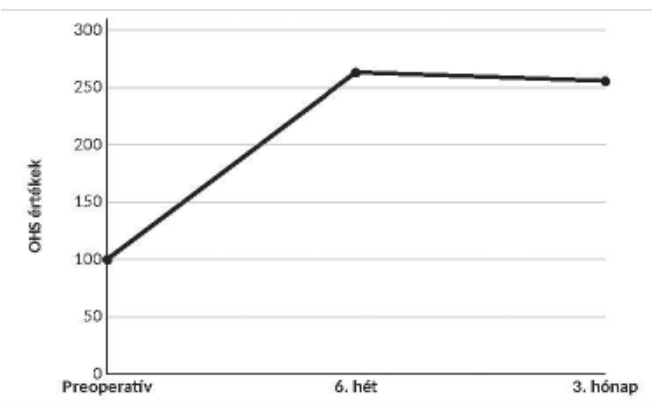

3. ábra

OHS pontszám százalékos javulása (átlag \pm SEM) az önkontrollos teszt alapján ( ${ }^{*}$ a szignifikanciát jelzi)

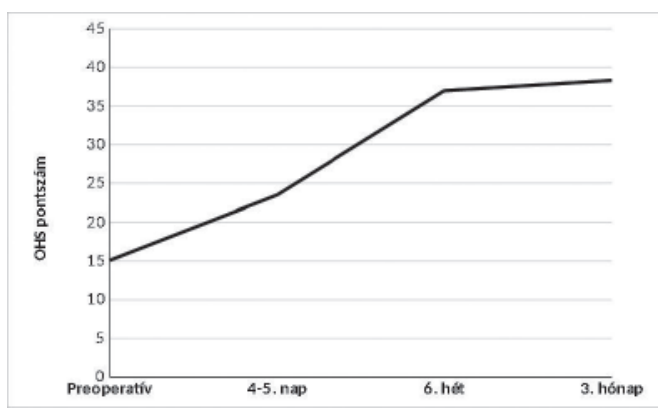

4. ábra

OHS pontszám javulása (átlag \pm SEM) a csoportátlagos értékek alapján ( ${ }^{*}$ a szignifikanciátjelzi)

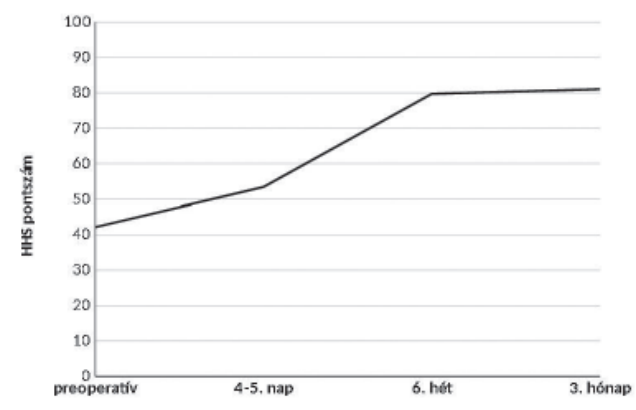

\section{5. ábra}

HHS pontszám javulása a mütét utáni 6. hétre és 3. hónapra (átlag \pm

SEM) a csoportátlagos értékek alapján ( ${ }^{*}$ a szignifikanciát jelzi)

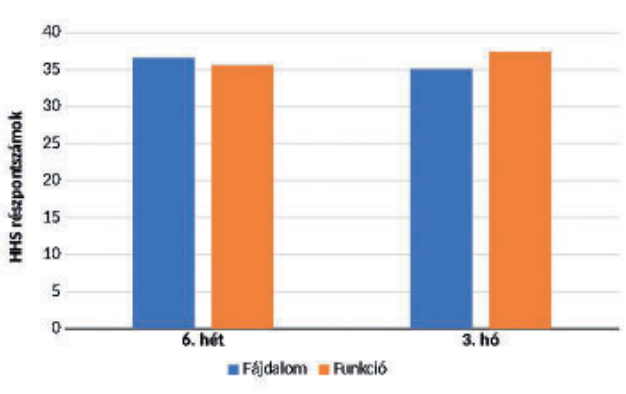

6. ábra

HHS fájdalom és funkció részpontszámok

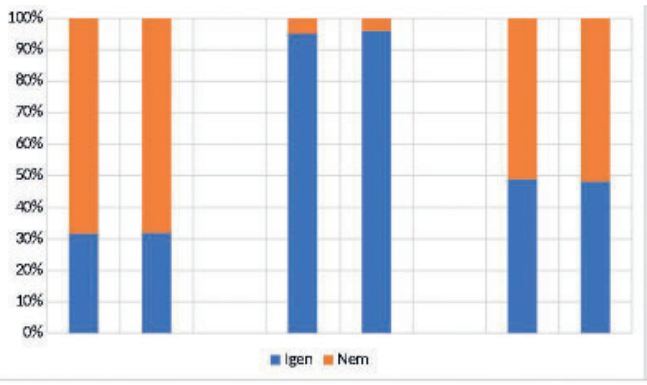

7. ábra

Kategorikus változók aránya 
I. táblázat Demográfiai adatok (átlag \pm SD)

\begin{tabular}{|c|c|c|c|}
\hline Esetszám: & 63 & TEP típusa: & \\
\hline Életkor (év): & $69,9 \pm 9,5$ & & $\begin{array}{l}\text { Cementes: } \mathbf{3} \\
\text { Cement nélküli: } \mathbf{5 1} \\
\text { Hibrid: } \mathbf{1}\end{array}$ \\
\hline Nő / Ffi: & $36 / 27$ & & $73 \pm 18$ \\
\hline $\begin{array}{c}\text { Oldaliság } \\
\text { (jobb / bal): }\end{array}$ & $38 / 25$ & Mútéti idő (perc): & $622 \pm 269$ \\
\hline BMI (kg/m2): & $28,1 \pm 3,9$ & Posztop. vérzés $(\mathbf{m l}):$ & \\
\hline
\end{tabular}

II. táblázat OHS és HHS pontszámok

\begin{tabular}{|c|c|c|c|c|}
\hline & preoperativ & 4-5. nap & 6. hét & 3. hónap \\
\hline OHS & $15,1 \pm 8,7$ & $23,5 \pm 10,9$ & $36,9 \pm 8,1$ & $38,32 \pm 8,9$ \\
\hline HHS & $42,2 \pm 15,1$ & $53,4 \pm 16,2$ & $79,7 \pm 14,0$ & $81,0 \pm 16,4$ \\
\hline
\end{tabular}

III. táblázat HHS részpontszámok és a kategorikus változók arányának változása

\begin{tabular}{|c|c|c|}
\hline & 6. hét & 3. hónap \\
\hline HHS fájdalom (0-44) & $36,6 \pm 8,7$ & $35,6 \pm 6,9$ \\
\hline HHS funkció (0-47) & $35,1 \pm 10,0$ & $37,4 \pm 7,4$ \\
\hline Korlátlan sétatáv & $31,70 \%$ & $32,00 \%$ \\
\hline Normális lépcsóhasználat & $95,10 \%$ & $96,80 \%$ \\
\hline $\begin{array}{c}\text { Cipó és zokni fel- és levétel } \\
\text { könnyedén }\end{array}$ & $48,80 \%$ & $48,00 \%$ \\
\hline
\end{tabular}




\section{MEGBESZÉLÉS}

A csípőízületi endoprotetika szerepe egyre jelentősebbé válik. Növekvő tendenciát mutat a coxarthrosis prevalenciája és ezzel párhuzamosan nő a végzett mútétek száma is. Az operációval szemben támasztott elvárások egyre nőnek, amely a mútéti eszközpark és a protézisek fejlesztése mellett a hatékonyabb sebészi feltárások és a mútéti technika fejlesztésének igényét is előtérbe helyezi. A totál csípőízületi endoprotézis beültetéshez használható különböző feltárások hosszú távú eredményei között nem található szignifikáns különbség $(2,12$, 19). Ezen okból kifolyólag a feltárások közötti preferencia kialakításában - természetesen a sebészi tapasztalat és a páciens adottságai mellett - a korai eredmények felé érdemes a figyelmet fordítani. Amellett, hogy a betegek számára a hamar javuló funkció és kisebb mértékű fájdalom igazán vonzó, a korai mobilizáció lehetőségét is megteremti, melynek velejárója a rövidebb hospitalizáció, az önellátás korai visszanyerése és a munkába való hamarabbi visszatérés. Utóbbi szempontot tovább hangsúlyozza, hogy a totál csípőprotézis beültetésre kerülő fiatalabb páciensek aránya egyre növekszik (9). Mindezek által nem csupán a pácienst tekintve jár előnyökkel a mütét utáni végleges funkció korábbi elérhetősége, de költséghatékonnyá, valamint szociális és gazdasági szempontból egyaránt előnyössé teszi a mútétet. Éppen ezért a feltárások fejlesztése a minimál invazivitás felé terelődött. A betegek gyorsabb felépülését elsősorban az izmok sérülése, az izmok beidegzésének károsodása gátolja, amelynek okozója lehet a mútéti feltárás részeként végzett izomátvágás, izomtapadás leválasztás, valamint a retraktorok által okozott izomrost roncsolódás és mozgató idegrost neuropraxia is. Természetesen a páciensek mútét előtti általános állapota, erőnléte, izomstátusza is meghatározó jelentőségű a mútét utáni funkció szempontjából. Minél kisebb az operált csípőízület funkciója szempontjából kritikus jelentőségű izmok (és azok beidegzésének) mútéti sérülése, annál inkább beszélhetünk minimál invazivitásról. A direkt anterior technika a csípőízületi feltárások között egyedüliként teszi lehetővé az endoprotézis intermuscularis és interneuralis téren keresztüli beültetését, mégpedig a nervus gluteus superior és a nervus femoralis idegek motoros ágrendszerének határterületén. Az irodalmi adatok alapján a direkt anterior feltárás a korai eredményeket tekintve előnyt élvez a többi feltárással szemben, amely különbség azonban a posztoperatív hatodik hónapra kiegyenlítődik $(2,12,19)$. Ez az általunk vizsgált hatodik heti adathoz képest a mútéttel nyert funkció végleges kialakulásának 18 hetes különbségét jelenti. Ehhez képest Restrepo és munkatársai szerint a direkt lateralis feltárással nyert eredmények csak a posztoperatív második évre érik el a direkt anterior feltárásban operált betegek eredményeit, amely még lényegesebb különbséget jelent (13).

Saját prospektív vizsgálatunkban részt vevő páciensek állapota funkció és fájdalom tekintetében a minimál invazív direkt anterior feltárásban végzett totál csípőízületi endoprotézis beültetést követően jónak bizonyult mind az OHS, mind a HHS pontrendszer alapján. E tekintetben az egyéb tanulmányokkal való összehasonlítás igencsak kérdéses, ugyanis a vizsgált populáció demográfiai adatai és a preoperatív pontszámok figyelembe vétele nem mellőzhető. További fontos tény, hogy mindezidáig nem készült olyan jellegű vizsgálat, amely egyazon feltárásban operált populáció funkciójavulásának mértékét vizsgálná különböző időpontokban. Az irodalomban a különböző feltárások összehasonlítására kiélezett tanulmányok találhatóak, amelyek kétféle feltárásban végzett mútét után a páciensek adott időpontban kapott pontszámait hasonlítják össze.

A kimeneteli eredményeket vizsgáló szenzitív pontrendszerek alkalmazásával detektálni tudtuk az eltéréseket és egyezéseket az elemzett időpontokban a betegek állapotát illetően. A mútéttel több, mint 163\%-os javulást tudtunk elérni a fájdalmak csökkenése és funkció javulása terén. Kiemelendő, hogy az OHS pontszámok alapján már a posztoperatív 4-5. napra, azaz a kórházból való elbocsátás idején rögzített értékek alapján is szignifikáns javulás volt detektálható a páciensek állapotában. Tanulmányunk demonstrálja, hogy a coxarthrosistól szenvedő betegek számára a csípőízületi totál endoprotézis beültetés által nyújtott végleges, javult funkció az elülső feltárás alkalmazása esetén már a posztoperatív hatodik hétre kialakul, hiszen az ezen időpontban regisztrált értékek megfelelnek a harmadik hónapban 
mért értékeknek. A direkt anterior feltárás nélkülözi az abduktorok disszekcióját, az abduktor izomcsoport erejét és intakt voltát pedig kulcsfontosságúnak tartjuk a korai eredmények szempontjából. Valószínúsíthető, hogy a lágyszöveti károsodás minimalizálása révén érhető el a fájdalom csekély mértéke már a hatodik posztoperatív hétre. Adataink szerint a mútét utáni fájdalom mértéke a hatodik héten megegyezik a harmadik hónapban mért értékekkel és ez a tendencia igaz a funkciót vizsgáló HHS részpontszám esetében is, tehát a funkció és a fájdalom azonos mértékben javul, és végleges értéke azonos időpontra alakul ki. Az önellátás szempontjából kiemelt fontossággal bíró, s ezért külön elemzésre került kategorikus változók is azt mutatták, hogy a hatodik posztoperatív hétre már elérik a páciensek a mútét által nyerhető javult funkciót. Kiemelendő, hogy a betegek közel egyharmadánál a járástávolság nem volt korlátozott, közel fele tudott cipót és zoknit könnyedén fel- és levenni, valamint majdnem az összes beteg képes volt normális lépcsőhasználatra már a mútét utáni hatodik héten.

A műtéti időtartam hasonlónak adódott, mint az irodalomban található hasonló operációs feltételek mellett (standard mútőasztalon, trakciós eszköz nélkül) direkt anterior feltárásban végzett totál csípőízületi endoprotézis beültetések esetén (3).

Mindezen előnyök mellett fontos kiemelni, hogy mint minden mútéti technika esetében, a minimál invazív direkt anterior feltárás alkalmazása során is mérlegelni kell az általa nyújtott előnyöket és a potenciális veszélyeket, főként a betanulási időszak alatt. Kellő előtanulmányokat és felkészülést követően, válogatott beteganyagon kezdett alkalmazása esetén azonban nem kell számolni megnövekedett komplikációrátával sem (7), így a direkt anterior feltárásból egyértelműen profitál a páciens, valamint nem elhanyagolható társadalmi-gazdasági előnyei is vannak a mútét utáni korai felépülésnek. 


\section{IRODALOM}

1. Alecci V., Valente M., Crucil M., Minerva M., Pellegrino C. M., Sabbadini D. D.: Comparison of primary total hip replacements performed with a direct anterior approach versus the standard lateral approach: perioperative findings. J. Orthop. Traumatol. 2011. 12. (3): 123-129. https://doi.org/10.1007/s10195-011-0144-0

2. Barrett W. P., Turner S. E., Leopold J. P.: Prospective randomized study of direct anterior vs postero-lateral approach for total hip arthroplasty. J. Arthroplasty, 2013. 28. (9): 1634-1638. https://doi.org/10.1016/i.arth.2013.01.034

3. Berend K. R., Lombardi Jr. A. V., Seng B. E., Adams J. B.: Enhanced early outcomes with the anterior supine intermuscular approach in primary total hip arthroplasty. J. BoneJoint Surg. Am. 2009. 91(suppl_65):107-120. https://doi.org/10.2106/ibjs.i.00525

4. Bergin P. F., Doppelt J. D., Kephart C. J., Benke M. T., Gaeter J. H., Holmes A. S., Haleem-Smith H., Tuan R. S., Unger A. S.: Comparison of minimally invasive direct anterior versus posterior total hip arthroplasty based on inflammation and muscle damage markers. J. Bone Joint Surg. Am. 2011. 93. (15): 1392-1398. https://doi.org/10.2106/ibjs.j.00557

5. Bourne M. H., Mariani E. M.: A comparison of direct anterior and lateral THA: postoperative outcome., J. Bone Joint Surg. Am. 2009. 91. 10.

6. Cheng T. E., Wallis J. A., Taylor N. F., Holden C. T., Marks P., Smith C. L., Armstrong M. S., Singh P. J.: A prospective randomized clinical trial in total hip arthroplasty - Comparing early results between the direct anterior approach and the posterior approach. J. Arthroplasty, 2017. 32. (3): 883-890. https://doi.org/10.1016/j.arth.2016.08.027

7. de Jonge T., Kelemen P., Pauka D., Torkos M.B.: Elülső feltárásból végzett minimál invazív csípőprotézis beültetéssel szerzett kezdeti tapasztalatok. Magyar Traumatológia Ortopédia Kézsebészet Plasztikai Sebészet, 2018. 61. 3-4. $129-138$. https://doi.org/10.21755/mto.2018.061.0304.005

8. Kurtz S., Ong K., Lau E., Mowat F., Halpern M.: Projections of primary and revision hip and knee arthroplasty in the United States from 2005 to 2030. J. Bone Joint Surg. Am. 2007. 89. (4): $780-785$. https://doi.org/10.2106/00004623-200704000-00012

9. Kurtz S. M., Lau E., Ong K., Zhao K., Kelly M., Bozic K. J.: Future young patient demand for primary and revision joint replacement: national projections from 2010 to 2030. Clin. Orthop. Relat. Res. 2009. 467. (10): $2606-2612$. https://doi.org/10.1007/s11999-009-0834-6

10. Leech, N. L., Barrett, K. C., Morgan G.. A.: IBM SPSS for intermediate statistics: Use and interpretation. 5. ed. New York. Routledge/Taylor \& Francis Group. 2015.

11. Meneghini R. M., Pagnano M. W., Trousdale R. T., Hozack W. J.: Muscle damage during MIS total hip arthroplasty: Smith-Petersen versus posterior approach. Clin. Orthop. Relat. Res. 2006. 453: $293-298$. https://doi.org/10.1097/01.blo.0000238859.46615.34

12. Nakata K., Nishikawa M., Yamamoto K., Hirota S., Yoshikawa H.: A clinical comparative study of the direct anterior with mini-posterior approach: two consecutive series. J. Arthroplasty, 2009. 24. (5): 698-704. https://doi.org/10.1016/i.arth.2008.04.012

13. Restrepo C., Parvizi J., Pour A. E., Hozack W. J.: Prospective randomized study of two surgical approaches for total hip arthroplasty. J. Arthroplasty, 2010. 25. (5): 671-679. https://doi.org/10.1016/i.arth.2010.02.002

14. Rodriguez J. A., Deshmukh A. J., Rathod P. A., Greiz M. L., Deshmane P. P., Hepinstall M. S., Ranawat A. S.: Does the direct anterior approach in THA offer faster rehabilitation and comparable safety to the posterior approach? Clin. Orthop. Relat. Res. 2014. 472. (2): 455-463. https://doi.org/10.1007/s11999-013-3231-0

15. Schweppe M. L., Seyler T. M., Plate J. F., Swenson R. D., Lang J. E.: Does surgical approach in total hip arthroplasty affect rehabilitation, discharge disposition, and readmission rate? Surg. Technol. Int. 2013. 23: 219-227.

16. Sheskin, D.: Handbook of parametric and nonparametric statistical procedures. BocaRaton. Chapman \& Hall/CRC. 2004.

17. Taunton M. J., Mason J. B., Odum S. M., Springer B. D.: Direct anterior total hip arthroplasty yields more rapid voluntary cessation of all walking aids: a prospective, randomized clinical trial. J. Arthroplasty, 2014. 29. (9. Suppl): $169-172$. https://doi.org/10.1016/i.arth.2014.03.051

18. Torkos M. B., Gimesi C., Tóth Z., Bajzik G., Magyar Á., Szabó I.: Comparative results of half year follow-up after primary total hip arthroplasty with minimally invasive anterior and direct lateral approach. J. Bone Joint Surg. 2012. 94-B. Suppl. 37: 124.

19. Wang Z., Hou J. Z., Wu C. H., Zhou Y. J., Gu X. M., Wang H. H., Feng W., Cheng Y. X., Sheng X., Bao H. W.: A systematic review and meta-analysis of direct anterior approach versus posterior approach in total hip arthroplasty. J. Orthop. Surg. Res. 2018. 13. (1): 229. https://doi.org/10.1186/s13018-018-0929-4

20. Zawadsky M. W., Paulus M. C., Murray P. J., Johansen M. A.: Early outcome comparison between the direct anterior approach and the mini-incision posterior approach for primary total hip arthroplasty: 150 consecutivecases. J. Arthroplasty, 2014. 29. (6): 1256-1260. https://doi.org/10.1016/j.arth.2013.11.013

\section{Dr. Gombos Ármin}

Markusovszky Egyetemi Oktatókórház

Traumatológiai és Kézsebészeti Osztály

9700 Szombathely, Markusovszky u. 5. 